ISSN: $2338-4794$

Vol.6. No. 1 Januari 2018

\title{
PENGARUH INFLASI, NILAI TUKAR, CURRENT RATIO (CR) DAN DEBT TO EQUITY RATIO (DER) TERHADAP HARGA SAHAM (Studi Kasus Pada PT. Eratex Djaja, Tbk Periode 2009-2011)
}

\author{
Muhammad Gusvarizon \\ Dosen Program Studi Manajemen Univ. Mohammad Husni Thamrin \\ Jl. Raya Bogor KM 20 Kramat Jati Jakarta Timur \\ Email: mgusvarizon@yahoo.co.id
}

\begin{abstract}
Abstrak: This study entitled "Influence Analysis of Inflation, Exchange Rate, Current Ratio (CR) and Debt to Equity Ratio (DER) on Stock Price (Case Study At PT Eratex Djaja, Tbk Listed on Indonesia Stock Exchange Period 2009 - 2011). In this research use survey research method with correlational and predictive approach. By taking sample that is PT. Eratex Djaja, Tbk Listed on Indonesia Stock Exchange Period of quarter 2009 - 2011. To solve the problem by analyzing and testing the relationship and influence between independent variable to dependent variable used by causalistic model through regression analysis with the help of SPSS 14.0. The result of this research is simultaneously Inflation, Exchange Rate, Current Ratio (CR) and Debt to Equity Ratio (DER) have positive and significant influence to Stock Price. Partially that: Inflation gives effect to Stock Price with influence of 44\% (strong enough), Exchange Rate gives influence to Share Price with influence of 56\% (strong enough), Current Ratio (CR) gives effect to Stock Price with influence equal to $76 \%$ (strong) and Debt to Equity Ratio (DER) give effect to Share Price with influence equal to $71 \%$ (strong).
\end{abstract}

Keywords: Inflation, Exchange Rate, Current Ratio (CR) and Debt to Equity Ratio (DER) and Stock Price

\section{PENDAHULUAN}

Pasar modal merupakan sarana yang efektif untuk mempercepat pertumbuhan perusahaan. Kehadiran pasar modal memperbanyak alternatif pilihan perusahaan untuk mendapatkan sumber dana (khususnya dana jangka panjang). Hal ini berarti keputusan pembelanjaan semakin bervariasi, sehingga struktur modal perusahaan dapat dioptimalkan.

Dalam company analysis para investor (pemodal) akan mempelajari laporan keuangan perusahaan dengan tujuan untuk menganalisis kinerja perusahaan dengan mengetahui kekuatan dan kelemahan perusahaan, mengidentifikasi kecenderungan dan mengevaluasi efisiensi operasional serta memahami sifat dasar dan karakter operasional perusahaan (Ang ,1997).
Pola perilaku harga saham menentukan pola returnyang diterima dari saham tersebut. Harga saham tidak hanya dipengaruhi profit perusahaan semata tetapi juga dipengaruhi faktor ekonomi, politik, dan keuangan suatu negara. Variabel makro yang mempengaruhi misalnya nilai tukar dan inflasi.

Faktor yang mempengaruhi harga saham adalah faktor internal perusahaan.Faktor internal yang digunakan dalam penelitian ini adalah Current Ratio (CR).Debt to Equity Ratio (DER). Perkembangan yang terjadi inilah yang salah satunya menjadi dasar untuk mengkaji lebih mendalam faktor-faktor apa sajakah yang diperkirakan dapat mempengaruhi harga saham perusahaan.

Berdasarkan penjelasan diatas, kajian dilakukan pada PT. Eratex Djaja, Tbk yaitu suatu perusahaan yang bergerak di bidang garment, terutama dalam pembuatan celana 
jeans. Dalam menjalankan roda perusahaan, data perkembangan harga saham tiap tahunnya PT. Eratex Djaja, Tbk mengalami fluktuasi. Besar kecilnya return saham menunjukkan kondisi yang tidak konsisten dengan harga saham.

Tingginya tingkat inflasi menunjukkan bahwa risiko untuk melakukan investasi cukup besar sebab inflasi yang tinggi akan mengurangi tingkat pengembalian (rate of return) dari investor. Pada kondisi inflasi yang tinggi maka harga barang-barang atau bahan baku memiliki kecenderungan untuk meningkat. Peningkatan harga barang-barang dan bahan baku akan membuat biaya produksi menjadi tinggi sehingga akan berpengaruh pada penurunan jumlah permintaan yang berakibat pada penurunan penjualan sehingga akan mengurangi pendapatan perusahaan.

Fluktuasi nilai tukar suatu mata uang juga dapat mempengaruhi kegiatan dan nilai pasar atas pasar lokal, jika perusahaan pada taraf persaingan internasional, hal ini berarti return saham perusahaan dipengaruhi oleh perubahan nilai tukar mata uang karena berdampak terhadap laporan perdagangan dan modal atas keseimbangan pembelian dalam negeri.

Semakin baik kinerja keuangan perusahaan yang tercermin dari rasiorasionya maka semakin tinggi returnsaham perusahaan, demikian juga jika kondisi ekonomi baik, maka refleksi harga saham akan baik pula. Perkembangan yang terjadi inilah yang salah satunya menjadi dasar untuk mengkaji lebih mendalam faktorfaktor apa sajakah yang diperkirakan dapat mempengaruhi harga saham pada perusahaan.

\section{METODE PENELITIAN}

\section{Populasi Dan Sampel Penelitian}

Populasi adalah wilayah generalisasi yang terdiri atas obyek atau subyek yang mempunyai kuantitas dan karakteristik tertentu yang ditetapkan oleh peneliti untuk dipelajari kemudian ditarik kesimpulannya (Sugiyono, 2005).Sampel adalah bagian dari karakteristik yang dimiliki oleh populasi tersebut. Apabila populasi besar, maka peneliti dapat menggunakan sampel yang diambil dari data populasi itu. Apa yang diperoleh dari penelitian sampel itu, kesimpulannya akan diberlakukan untuk populasi. Untuk itu sampel yang diambil dari populasi harus betul-betul representatif atau mewakili (Sugiyono, 2008).

Populasi penelitian ini adalah data keuangan dengan Inflasi, Nilai Tukar, Current Ratio (CR) dan Debt to Equity Ratio (DER) PT. Eratex Djaja, Tbk yang terdaftar di Bursa Efek Indonesia (BEI), periodisasi populasi penelitian mencakup data perusahaan manufaktur yang Listing di Bursa Efek Indonesia Per Triwulan dari periode 2009 sampai dengan 2011, sedangkan sampel unit data dipergunakan data Per Triwulan periode 2009 - 2011. Memperhatikan pola data yang ada menggunakan Inflasi, Nilai Tukar, Current Ratio (CR) dan Debt to Equity Ratio (DER) dimana pada tahun tersebut sering terjadi fluktuasi data yang naik turun, maka sampel data dianggap representative adalah tiap Per Triwulan periode 2009 - 2011 . 


\section{DESAIN PENELITIAN}

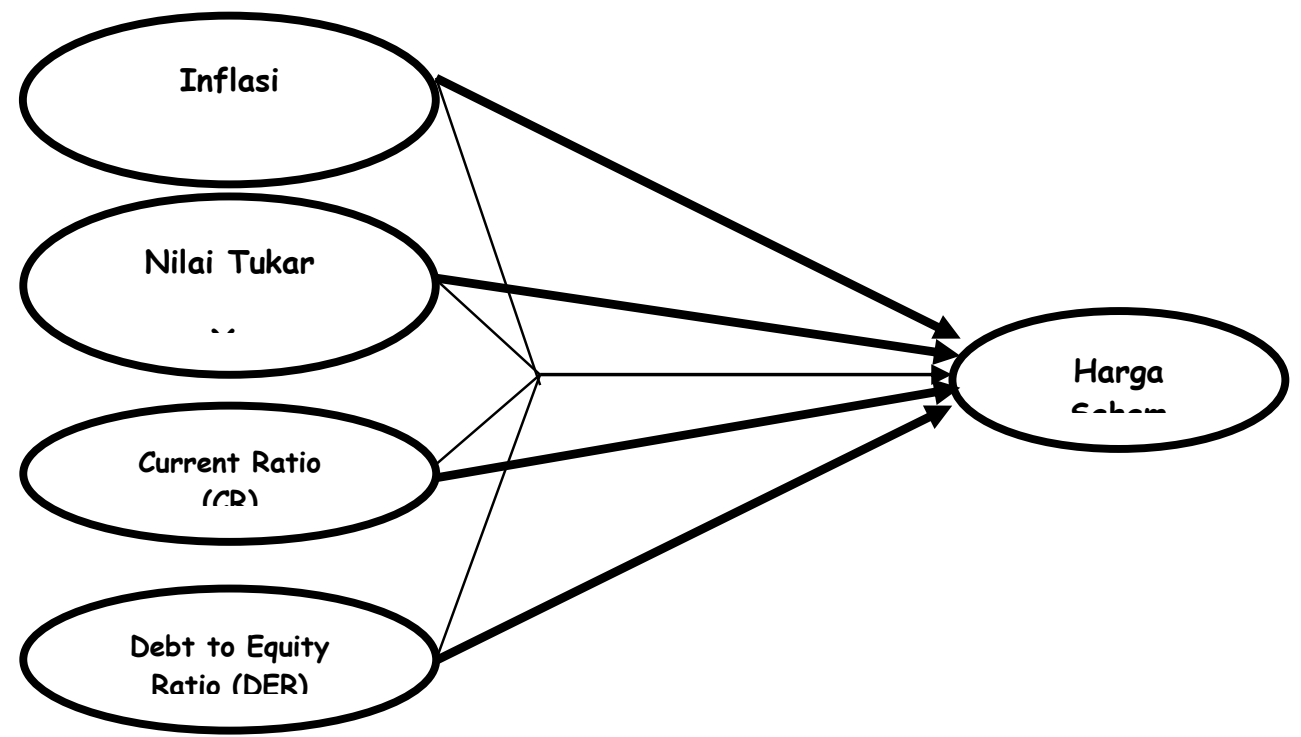

\section{HIPOTESIS}

Berdasarkan kerangka pemikiran dalam penelitian ini maka kriteria pengujian hipotesis adalah : a). Secara simultan Inflasi, Nilai Tukar, Current Ratio (CR) dan Debt to Equity Ratio (DER)berpengaruh positif dan signifikan terhadap Harga Saham b). Secara parsial Inflasi) berpengaruh positif dan signifikan terhadap Harga Saham. c). Secara parsial Nilai Tukar berpengaruh positif dan signifikan terhadap Harga Saham. d). Secara parsial Current Ratio (CR) berpengaruh positif dan signifikan terhadap Harga Saham. e). Secara parsial Debt to Equity Ratio (DER) berpengaruh positif dan signifikan terhadap Harga Saham.

\section{Uji Asumsi BLUE}

Sebelum melakukan pengujian hipotesis, terlebih dahulu dilakukan pengujian apakah model yang terbentuk layak digunakan sebagai model yang berperilaku sebagai model prediktor, artinya penduga yang dihasilkan merupakan penduga yang benar, tidak bias dan dapat diprediksikan.

Untuk mengetahui kelayakan model yang dihasilkan dalam suatu hubungan simultan, model dapat diuji dengan menggunakan 5 asumsi BLUE (Best Linear Unbiased Estimator). Keempat asumsi tersebut adalah asumsi multikolinearitas heteroskedasitas, normalitas, linearitas dan autokorelasi. Berikut ini adalah pengujian kelayakan model terhadap asumsi-asumsi BLUE (Kutner H. Michael, 2005).

\section{Multikolinearitas \\ Uji t}

Hasil pengolahan data dengan SPSS 14.0 menunjukkan bahwa $\mathrm{Ta}=28.142$ pada signifikansi $\mathrm{Ta}=0.000$, sedangkan $\mathrm{Tx}_{1}=$ 1.228 pada signifikansi $\mathrm{Tx}_{1}=0.006, \mathrm{Tx}_{2}=$ 5.414 pada signifikansi $\mathrm{Tx}_{2}=0.001$ sedangkan $\mathrm{Tx}_{3}=9.397$ pada signifikansi $\mathrm{Tx}_{3}=0.000$, lalu $\mathrm{Tx}_{4}=7.164$ pada signifikansi $\mathrm{Tx}_{4}=0.000$. Melalui uji t yang dilakukan diatas teridentifikasi bahwa, secara keseluruhan t hitung yang dihasilkan dominan relatif lebih besar dibandingkan $\mathrm{t}$ signifikannya, untuk alfa $(\alpha)=0.01$ 
pengujian tersebut membuktikan bahwa, model tidak menemui kendala multikolinearitas.

\section{Uji VIF}

Faktor Total Asset Ragam (Variance Inflation Factor $=$ VIF). Hal ini dikarenakan terdapat lebih dari 2 variabel Independent atau variable bebas, yaitu apabila nilai $\mathrm{VIF}_{1}$ masing - masingvariabel< dari 10. Nilai $\mathrm{VIF}_{1}=0.55<10$, Nilai $\mathrm{VIF}_{2}=0.62<10$, Nilai $\mathrm{VIF}_{3}=0.89<10$, Nilai $\mathrm{VIF}_{4}=0.77<$ 10. Melalui Uji Colinierity Statistic yang dilakukan diatas teridentifikasi bahwa, secara keseluruhan nilai VIF yang dihasilkan dominan relatif lebih kecil dari 10 , pengujian tersebut membuktikan bahwa, nilai yang dihasilkan menunjukkan tidak adanya kendala Multicollinearity dalam model.

\section{Heteroskedasitas}

Uji heteroskedasitas dimaksudkan untuk mengetahui apakah dalam model regresi terjadi ketidaksamaan varian dari residual satu pengamatan ke pengamatan yang lain. Jika varian dari residual satu pengamatan ke pengamatan lain berbeda maka disebut heteroskedasitas. Model yang baik harus terbebas dari heteroskedasitas atau dengan kata lain harus homoskedasitas yaitu varian dari residual satu pengamatan ke pengamatan lain adalah tetap, oleh karena itu pengujian ini hanya diperuntukan bagi hubungan simultan saja.

Untuk menentukan ada atau tidak adanya heteroskedasitas dalam penelitian ini di lakukan dengan cara melihat grafik scatterplot antara nilai prediksi variabel dependen (ZEPRED) dengan residualnya (SRESID). Dasar analisisnya (1) jika ada pola tertentu, seperti titik-titik yang ada membentuk pola tertentu yang teratur (bergelombang, melebar kemudian menyempit) maka mengindikasikan telah terjadi heteroskedasitas, (2) jika tidak ada pola yang jelas serta titik-titik menyebar di atas dan di bawah angka 0 pada sumbu Y, maka tidak terjadi heteroskedasitas (Ghozali, 2005).

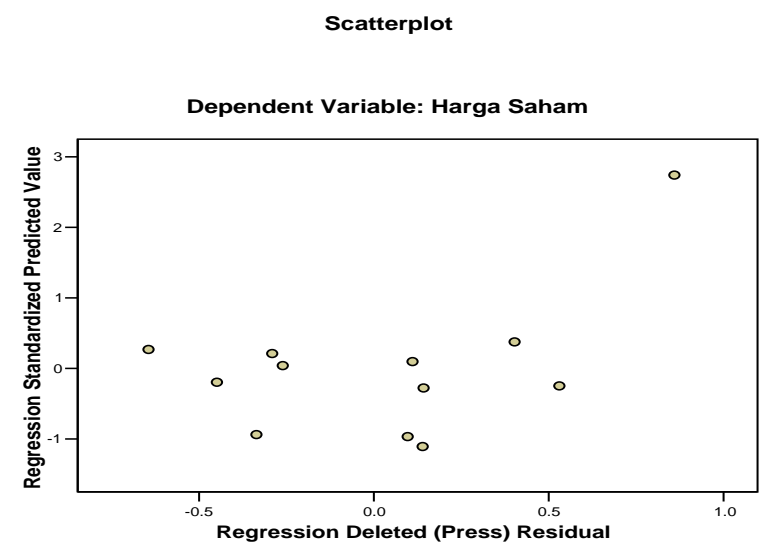

Berdasarkan grafik scatterplot di atas antara SRESID dan ZPRED di mana sumbu $\mathrm{Y}$ adalah $\mathrm{Y}$ yang telah diprediksi dan $\mathrm{X}$ adalah residual ( $\mathrm{Y}$ prediksi dengan $\mathrm{Y}$ sesungguhnya) yang memperlihatkan titiktitik menyebar secara acak, tidak membentuk sebuah pola tertentu yang jelas serta tersebar baik di atas maupun di bawah angka 0 pada sumbu Y. Dapat disimpulkan bahwa tidak terjadi heteroskedasitas pada model regresi.

\section{Normalitas}

Untuk dapat mengetahui apakah data Sampel berasal dari data yang terdistribusi Normal, maka perlu diadakan Uji sampel (KS) Kolmosgorov - Smirnov yaitu apabila Asymp. Sig > taraf Signifikan ( ) atau nilai yang dihasilkan adalah dapat di lihat pada tabel berikut ini : 


\begin{tabular}{|c|c|c|c|}
\hline No & Normalitas & Syarat & Nilai Yang dihasilkan \\
\hline 1 & $\begin{array}{l}X_{1,} X_{2}, X_{3} \\
X_{4} \rightarrow Y\end{array}$ & $\begin{array}{l}\text { Normalitas } \\
\text { Kol.Sirnov Test }>\alpha(\text { A Symp Sig. T }>\alpha)\end{array}$ & Terpenuhi dengan nilai $0.256>0.01$ \\
\hline 2 & $X_{I} \rightarrow Y$ & $\begin{array}{l}\text { Normalitas } \\
\text { Kol.Sirnov Test }>\alpha(\text { A Symp Sig. T }>\alpha)\end{array}$ & Terpenuhi dengan nilai $0.127>0.01$ \\
\hline 3 & $X_{2} \rightarrow Y$ & $\begin{array}{l}\text { Normalitas } \\
\text { Kol.Sirnov Test }>\alpha(\text { A Symp Sig. T }>\alpha)\end{array}$ & Terpenuhi dengan nilai $0.149>0.01$ \\
\hline 4 & $X_{3} \rightarrow Y$ & $\begin{array}{l}\text { Normalitas } \\
\text { Kol.Sirnov Test }>\alpha(\text { A Symp Sig. } T>\alpha)\end{array}$ & Terpenuhi dengan nilai $0.227>0.01$ \\
\hline 5 & $X_{4} \rightarrow Y$ & $\begin{array}{l}\text { Normalitas } \\
\text { Kol.Sirnov Test }>\alpha \text { (A Symp Sig. T }>\alpha)\end{array}$ & Terpenuhi dengan nilai $0.202>0.01$ \\
\hline
\end{tabular}

Sumber: Data Primer, diolah tahun 2012

Selain uji KS, untuk menguji normalitas data juga dilakukan dengan analisis grafik. Analisis grafik untuk menguji normalitas data adalah dengan melihat histogram yang membandingkan antara data observasi dengan distribusi yang mendekati distribusi normal atau dengan melihat normal probability plot yang membandingkan distribusi kumulatif dari data sesungguhnya dengan distribusi kumulatif dari distribusi normal.

\section{Linearitas}

Uji linearitas digunakan untuk memastikan apakah hubungan antara variabel bebas dengan variabel terikat bersifat linear atau tidak. Hubungan antara variabel X dan Y dikatakan linear bilamana laju perubahan dalam Y (Harga Saham) yang berhubungan dengan perubahan satu satuan X Inflasi, Nilai Tukar, Current Ratio (CR) dan Debt to Equity Ratio (DER) adalah konstan untuk satu jangkauan nilai-nilai. Analisis yang digunakan dalam penelitian ini adalah analisis normal probability plot dan perbandingan probability dengan $\alpha$. Analisis linearitas pada tiap-tiap hubungan, terlihat pada tabel berikut ini :

\begin{tabular}{lllll}
\hline No & Normalitas & Syarat & Gambar Histogram dan Grafik Normal Plot & Keputusan \\
\hline $\mathbf{1}$ & $X_{1}, X_{2}, X_{3}$, & Sig.F $<$ & $\begin{array}{l}\text { Signifikansi F }(0,000) \text { lebih kecil dari Alfa } \\
(0.01) .\end{array}$ & Linier \\
& $X_{4} \rightarrow Y$ & Sig.F $<$ & $\begin{array}{l}\text { Signifikansi F }(0.006) \text { lebih kecil dari Alfa } \\
(0.01) .\end{array}$ & Linier \\
$\mathbf{2}$ & $X_{1} \rightarrow Y$ & Sig.F $<$ & $\begin{array}{l}\text { Signifikansi F }(0.001) \text { lebih kecil dari Alfa } \\
(0.01) .\end{array}$ & Linier \\
$\mathbf{3}$ & $X_{2} \rightarrow Y$ & Sig.F $<$ & $\begin{array}{l}\text { Signifikansi F }(0.000) \text { lebih kecil dari Alfa } \\
(0.01) .\end{array}$ & Linier \\
$\mathbf{4}$ & $X_{3} \rightarrow Y$ & Signifikansi F $(0.000)$ lebih kecil dari Alfa & Linier \\
\hline
\end{tabular}




\section{Autokorelasi}

Uji Autolorelasi digunakan untuk memastikan apakah terjadi korelasi antar residual satu obeservasi dengan observasi lain. Penentuan ada tidaknya autokorelasi dapat diamati dengan perolehan DW sebesar 2,255 dimana untuk DW adalah $1,65<$ DW $<2,35$ atau $1,65<2,255<2,35$

\section{PENELITIAN DAN PEMBAHASAN}

Pengaruh Simultan Inflasi, Nilai Tukar, Current Ratio (CR) dan Debt to Equity Ratio (DER) Terhadap Harga Saham

\begin{tabular}{lcccccc}
\hline \multirow{2}{*}{ Model } & \multicolumn{5}{c}{ Parameter } \\
\cline { 2 - 7 } & $\begin{array}{c}\text { R } \\
\text { Square }\end{array}$ & $\begin{array}{c}\text { Std. Error of } \\
\text { The } \\
\text { Estimeted }\end{array}$ & t hitung & Sig. & VIF & DW \\
\hline Contstanta & & & 28.142 & 0.000 & - & \\
Inflasi & & & 1.228 & 0.006 & 0.55 & \\
Nilai Tukar & 0.976 & 2.58439 & 5.414 & 0.001 & 0.62 & 2.255 \\
CR & & & 9.397 & 0.000 & 0.323 & \\
DR & & & 7.164 & 0.000 & 0.077 & \\
\hline
\end{tabular}

Keterangan: Variabel Harga Saham

Sumber: data diolah

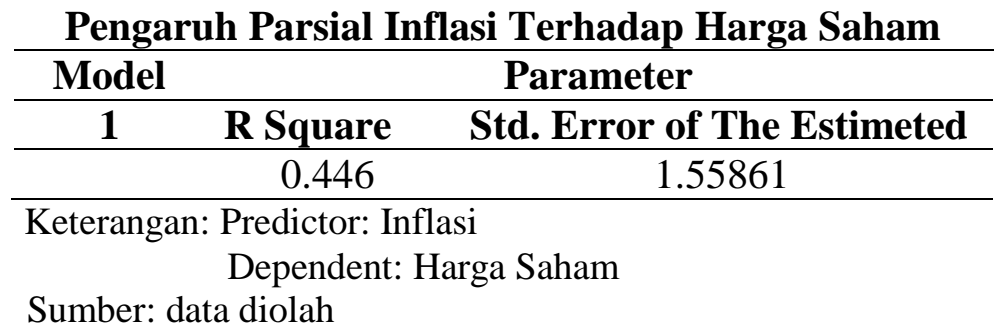

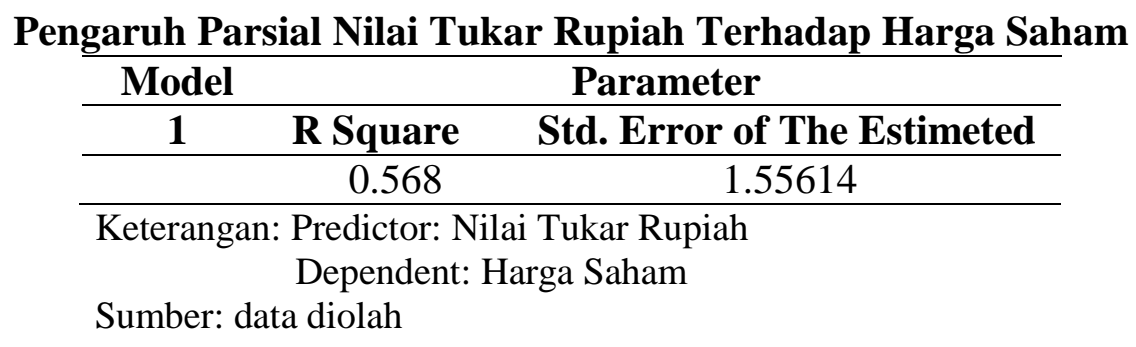

Pengaruh Parsial Current Ratio (CR) Terhadap Harga Saham

\begin{tabular}{|c|c|c|}
\hline $\begin{array}{c}\text { Model } \\
1\end{array}$ & \multicolumn{2}{|r|}{ Parameter } \\
\hline \multirow[t]{2}{*}{1} & R Square & Std. Error of The Estimeted \\
\hline & 0.767 & 2.49566 \\
\hline Keteranga & $\begin{array}{l}\text { Predictor: } \\
\text { Dependent }\end{array}$ & $\begin{array}{l}\text { ent Ratio } \\
\text { rga Saham }\end{array}$ \\
\hline
\end{tabular}




\section{Pengaruh Parsial Debt to Equity Ratio (DER) Terhadap Harga Saham

\begin{tabular}{ccc}
\hline Model & & Parameter \\
\hline $\mathbf{1}$ & R Square & Std. Error of The Estimeted \\
\hline & 0.717 & 2.49686 \\
\hline
\end{tabular} \\ Keterangan: Predictor: Debt to Equiaty Ratio Dependent: Harga Saham \\ Sumber: data diolah}

\section{KESIMPULAN}

Setelah dilakukan penelitian analisis Inflasi, Nilai Tukar, Current Ratio (CR) dan Debt to Equity Ratio (DER) terhadap Harga Saham PT. Eratex Djaja, Tbk yang termaksud di Bursa Efek Indonesia tiap Per Triwulan periode 2009 sampai dengan tahun 2011, maka dapat ditarik kesimpulan yang merupakan jawaban permasalahan untuk mencari tujuan penelitian dan sekaligus pembuktian hipotesis.

Secara simultan Inflasi, Nilai Tukar, Current Ratio (CR) dan Debt to Equity Ratio (DER) berpengaruh positif dan signifikan terhadap Harga Saham, hal tersebut ditunjukkan dengan perolehan $(R$ Square $=0.976$ dengan estimasi residual yang explaned Residual atau sebesar 2.58439). Kondisi ini juga mampu menjelaskan, bahwa Inflasi, Nilai Tukar, Current Ratio (CR) dan Debt to Equity Ratio (DER)secara simultan memberikan prediksi positif terhadap Harga Saham yang dalam hal ini dapat dijelaskan dengan pengaruh sebesar 97\% (sangat kuat) dan sisanya atau sebesar $0.3 \%$ adalah sebagai Estimasi residual yang Unexplaned Residual dan sisanya dipengaruhi oleh variabel lain di luar model.

Secara parsial Inflasi terhadap Harga Saham, hal tersebut ditunjukkan dengan perolehan $(R$-Square $=0.446$ dengan estimasi residual yang explaned Residual atau sebesar 1.55861). Kondisi ini juga mampu menjelaskan, bahwa Inflasi secara parsial memberikan pengaruh terhadap
Harga Saham dengan pengaruh sebesar $44 \%$ (cukup kuat).

Secara parsial Nilai Tukar terhadap Harga Saham, hal tersebut ditunjukkan dengan perolehan $(R$-Square $=0.568$ dengan estimasi residual yang explaned Residual atau sebesar 1.55614). Kondisi ini juga mampu menjelaskan, bahwa Nilai Tukar secara parsial memberikan pengaruh terhadap Harga Saham dengan pengaruh sebesar 56\% ( cukup kuat).

Secara parsial Current Ratio (CR) terhadap Harga Saham, hal tersebut ditunjukkan dengan perolehan $(R$-Square $=$ 0.767 dengan estimasi residual yang explaned Residual atau sebesar 2.49566). Kondisi ini juga mampu menjelaskan, bahwa Current Ratio (CR)secara parsial memberikan pengaruh terhadap Harga Saham dengan pengaruh sebesar $76 \%$ (kuat).

Secara parsial Debt to Equity Ratio (DER) terhadap Harga Saham, hal tersebut ditunjukkan dengan perolehan $(R$-Square $=$ 0.717 dengan estimasi residual yang explaned Residual atau sebesar .249686). Kondisi ini juga mampu menjelaskan, bahwa Debt to Equity Ratio (DER) secara parsial memberikan pengaruh terhadap Harga Saham dengan pengaruh sebesar $71 \%$ (kuat). 


\section{REKOMENDASI}

Berdasarkan analisa penelitian, kesimpulan dan kenyataan yang ada, beberapa saran perlu dipertimbangkan yaitu : a). Bagi pihak investor, hendaknya memperhatikan informasi mengenai variabel inflasi sebelum mulai berinvestasi. Dengan memperhatikan informasi mengenai variabel-variabel tersebut diharapkan investor mendapatkan returnsesuai dengan yang diharapkan, disamping risiko yang dihadapi. b). Bagi perusahaan harus mengatur komposisi antar utang dan modal agar utang optimal. Penggunaan utang secara optimal dapat memberikan leverage (daya ungkit) pada laba bersih, sehingga laba bersih perusahaan meningkat. c). Bagi perusahaan harus dapat menjaga tingkat kesehatan perusahaan, baik dari faktor permodalan, kualitas aktiva produktif, manajemen, rentabilitas, likuiditas. Jika kelima faktor tersebut terjaga dengan baik maka krisis pada perusahaan tidak akan terjadi dan kepercayaan masyarakat tetap terjaga dengan baik sehingga perusahaan dapat berjalan dengan baik. Dengan demikian perusahaan membantu terciptanya perekonomian suatu Negara.

\section{DAFTAR PUSTAKA}

Adiningsih, Sri dkk. 1998. Perangkat Analisis dan Teknik Analisis Investasi di Pasar Modal Indonesia.Jakarta: P.T. Bursa Efek Jakarta.

Algifari, 1997. Analisis Regresi, Teori, Kasus dan Solusi, edisi pertama, Penerbit BPFE UGM, Yogyakarta.
Amin Widjaja Tunggal, 1995. Dasar-Dasar Analisis Laporan Keuangan. Cetakan Pertama, Jakarta. PT. Rineka Cipta.

Ang, Robert, 1997. Buku Pintar Pasar Modal Indonesia. Mediasoft, Jakarta.

Harahap, Sofyan, Syafri, 2007. Analisis Krisis Atas Laporan Keuangan, Cetakan Kedua, Penerbit PT. Raja Grafindo Persada. Jakarta.

Karina, Cahyati, 2006. Analisis Faktorfaktor Yang Mempengaruhi Dividen Per Share Pada Perusahaan Manufaktur Yang Terdaftar Di Bursa Efek Jakarta. Skripsi. Universitas Islam Indonesia, Yogyakarta.

L. Thian Hin, 2001, Panduan Berinvestasi Saham, Jakarta: Elex Media Komputindo

Lind, 2002."The Effectiveness of Price Limits When Investors Are Offerconfident", National Lien-Ho Institute of Technology-Taiwan Working Paper.

Nopirin. 2000. Ekonomi Moneter. Buku II. Edisi ke 1. Cetakan Kesepuluh. Yogyakarta. BPFE UGM.

Permadhy, Yul Tito. 2005. Pengambilan Keputusan Berinvestasi di Pasar Modal.http://jurnal.pdii.lipi.go.id/ad min/jurnal/21053843.pdf.

Sofiati, 2000.Pengaruh Timbal Balik Antara Utang dan Ekuitas Terhadap Struktur Modal PerusahaanPerusahaan Go Publik di Bursa Efek Jakarta. Yogyakarta : STIE Yo.

Sugiyono, 2005. Metode Penelitian Kualitatif, Bandung : Alfabeta.

Winarno Surakhmad, 1990. Pengantar PenelitianIlmiah. Edisi Ketujuh. Cetak Ulang Keempat Kali. Penerbit Tarsito. Bandung. 